\title{
RENEWABLE ENERGY RESOURCES POTENTIAL IN TURKEY, PRODUCTION AND CONSUMPTION
}

\author{
Taner Dindar ${ }^{1}$, Ali Samet Sarkin ${ }^{2}$, Necmi Cemal Özdemir ${ }^{3}$ \\ ${ }^{1}$ Ankara University Nallıhan Vocational High School \\ Nallıhan, Ankara, Turkey, mobile: +905495501987, e-mail: tdindar@ankara.edu.tr \\ ${ }^{2}$ Osmaniye Korkut Ata University Kadirli Vocational High School \\ Kadirli, Osmaniye, Turkey, mobile: +905066533933, e-mail: sametsarkin@osmaniye.edu.tr \\ ${ }^{3}$ Kocaeli University Electrical Engineering \\ Kocaeli, Turkey, +905498601811, e-mail: necmi.ozdemir41@hotmail.com
}

\begin{abstract}
The purpose of study; to analysis and the development of alternative energy sources years to years and numerically analysis them. Regarding to BP Energy Statistic Report 2016; renewable energy production has increased percent 15,2 on electricty production total. It can be shown analysis that renewable enegy sources is the enegy sources of the future. Since 2010, The Turkish goverment policies related to renewable energy sources in the World has been published and efforts are being made to focus on this issue for the future. The country which have good planing on work will meet a large percentage of energy demand through renewable energy. This paper aims to analysis the situation and potential of Turkey in terms of clean and renewable energy and to plan for the future energy policy.
\end{abstract}

Keywords: Renewable Energy, Wind Energy, Analysis of Energy.

\section{INTRODUCTION}

Renewable energy sources are those, which can be produced on the earth and in the nature without the need for any generation process, during which $\mathrm{CO}_{2}$ emissions are produced at a low level or none, on which the damage to the environment is lower than other energy sources, constantly renewed, clean and natural sources of energy such as wind, sun, geothermal, biomass, biogas, wave, current energy and tide.

There is a rapidly increasing demand for energy over time. International studies show that environmental leases arising from other fuels have increased, thus accelerating policies that support the use of renewable energy sources seen to be "clean" compared to other sources, making a positive contribution to the environment in terms of their use. The share of the use of renewable resources in total energy production is around $19 \%$ in 2006 , but it is up to $20 \%$ in 2011 and $25 \%$ in 2018 thanks to increased work [1].

Our country, which has a significant potential in terms of renewable energy, ranks 7th in the world with its geothermal potential. In addition to this energy source, priority is given to the development of hydroelectric sources as well as wind and solar energy. According to the "Turkish National Renewable Energy Action Plan", the hydroelectricity installed capacity of 20.000 MW in 2023, the capacity of the wind energy capacity of $20.000 \mathrm{MW}$; Solar energy capacity to $3,000 \mathrm{MW}$ and geothermal energy capacity to $1,000 \mathrm{MW}, 30 \%$ of total electricity production is planned to be generated from renewable energy [2].

\section{INVESTIGATION OF RENEWABLE ENERGY RESOURCES USED IN THE WORLD}

Energy consumption, population growth, urbanization, industrialization, and the spread of technology all over the world are increasing. Non-renewable energy sources, on the other hand, are continuously decreasing in the world, inversely proportional to energy demand [3].

IRTIIE Vol. 5, No. 1, 2015 ISSN 1314-8788 (print), ISSN 1314-8796 (online), doi: 10.15547/artte.2017.01.006 


\section{AR'T'TE

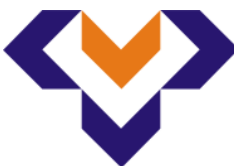 \\ Ipplied Resseirlohes in Technics, Technologies and Bductation \\ Journal of the Faculty of Technics and Technologies, Trakia University https://sites.google.com/a/trakia-uni.bg/artte/}

While the energy consumption used in the world is increasing, different methods are being sought in energy production. The most noteworthy of the different methods is the energy generated from renewable energy sources, which are increasing in the year. The increased energy generated from renewable energy sources can be seen in Figure 1.

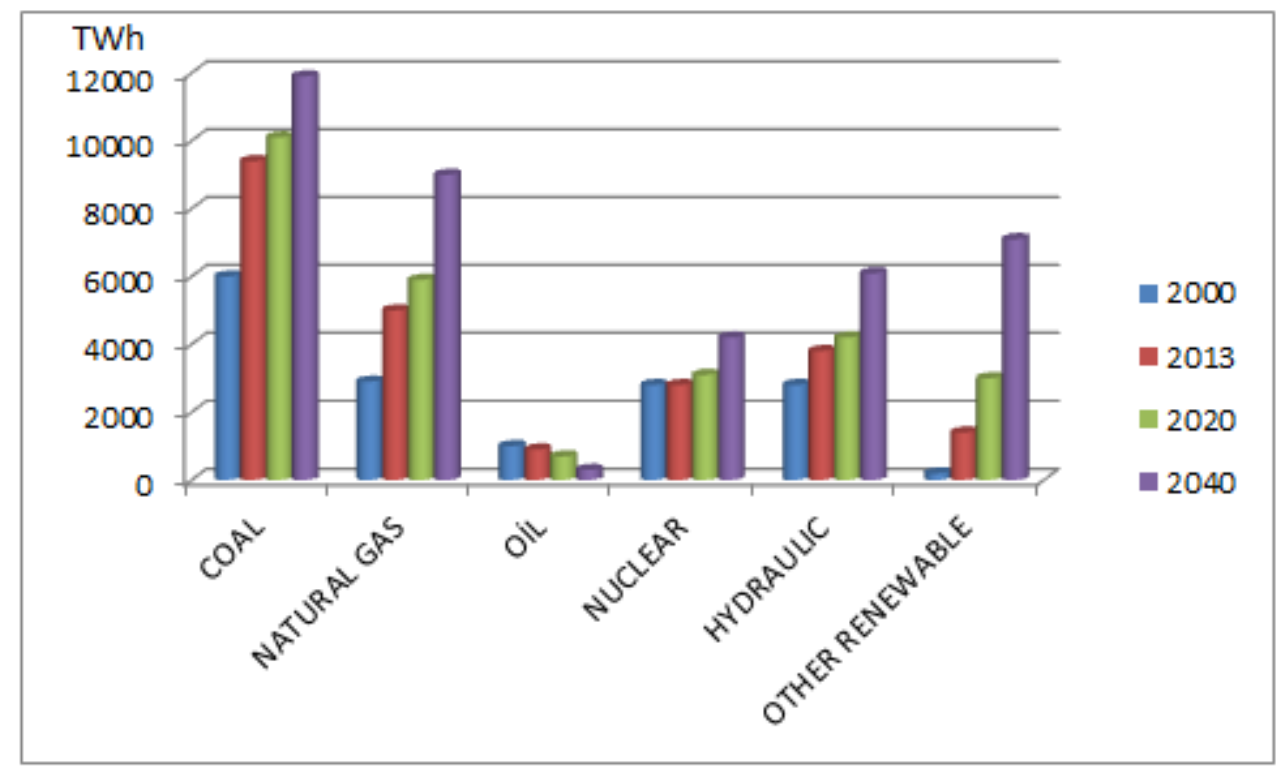

Figure 1. Shares of Energy Resources in the World Electricity Generation when the New Policy Scenario is Considered (2000-2040) [4]

It is observed that the capacity of renewable energy usage in the world between 2010 and 2013 increased by a third. According to past years, the reason for this increase is that the installed power capacity of wind and solar energy is used more than other sources. The installed capacity of wind energy in the world has increased by 17 percent since 2010 and costs have fallen by 45 percent. In the same period, the installed capacity in solar energy increased by 37 percent, while costs decreased by about 80 percent. Hydroelectric energy capacity increased by $3 \%$, bioenergy and geothermal energy increased by $5 \%$ [3].

Between 2004 and 2015, renewable energy investments increased by $38 \%$ in China, $21 \%$ in the US and $6 \%$ in the European Union. Worldwide, renewable energy investments increased by $18 \%$ in the same period. The US and China, which are the largest producers of greenhouse gas emissions, show an increase above the world average, proving their willingness on renewable energy [8].

The world economy, population growth, industrialization and urbanization in the world, which are expected to grow at an average rate of $3.5 \%$ in the long term (2013-2040), significantly increase demand for natural resources and energy. Estimation studies indicate that in the continuation of current energy policies, the world energy demand in 2040 will increase by 1.38 percent year on year, to 44.9 percent (13.559 million tons of equivalent oil (Mtoe) to 19.643 Mtoe). The 90.7 percent of the increase in demand is estimated to be in non-OECD countries (especially in China and India) where the economic growth rates are expected to be high (4.5 percent annual average) in the period 2013-2040 and with a rapid population growth rate (annual average of 1 percent), with an average annual value of $2.0 \%$. In the same period, annual average gross domestic product (GDP) increase is expected to be $1.9 \%$, while in OECD countries it is expected to increase by an annual average of $0.2 \%$. China is in the first place in energy consumption in 2013 and it is estimated that the US, 


\section{ARTTIE $Y$}

Ipplied Resseirl'hes in Teednicis, Technologies and Eductation

Journal of the Faculty of Technics and Technologies, Trakia University https://sites.google.com/a/trakia-uni.bg/artte/

which is expected to be second in 2040, will consume about $94 \%$ more energy than the energy consumed in the past years. After 2030, India is predicted to be the future of these countries. As noted, these four countries will consume about $56 \%$ of the total energy demand in the world. By the year 2040, it is equal to $53.9 \%$ of the population over all consumed energy. In order for the increase in world energy demand to be met on a sustainable basis, it is estimated that in the 2015-2040 period, an investment worth about 68 trillion US dollars (2014 figures) is needed in the energy sector [4].

It is thought that the installed power ratio of renewable energy sources other than hydropower will increase from $9.6 \%$ in 2013 to $15.2 \%$ in $2020,18.5 \%$ in 2030 and $20.7 \%$ in 2040. For hydraulics, it is predicted to decrease from $19.3 \%$ to $16.4 \%$ in the same period. In the production of renewable energy sources, the future of wind and solar energy is considered. It is expected that the share of renewable energy sources in electricity generation will reach $25.2 \%$ in 2020 and $26.6 \%$ in 2040 from $21.9 \%$ (2013)[4].

In Table 1 it is expected that other renewable energy sources and bioenergy will increase $117 \%$ in 2020 new policy scenario. When the current policy scenario is examined, it is estimated that renewable energy sources will increase. Other sources are likely to increase, but not as much as renewable energy sources.

Table 1. World Primary Energy Demand (million ton oil equivalent - mtpe) [5]

\begin{tabular}{|c|c|c|c|c|c|}
\hline & 2012 & $\begin{array}{c}\text { New policy } \\
\text { scenario } \\
2020\end{array}$ & $\begin{array}{c}\text { New policy } \\
\text { scenario } \\
2040\end{array}$ & $\begin{array}{c}\text { Current } \\
\text { policy } \\
\text { scenario } \\
2020\end{array}$ & $\begin{array}{c}\text { Current } \\
\text { policy } \\
\text { scenario } \\
2040\end{array}$ \\
\hline Coal & 3.879 & 4.211 & 4.448 & 4.457 & 5.860 \\
\hline Oil & 4.194 & 4.487 & 4.761 & 4.584 & 5.337 \\
\hline Natural Gas & 2.844 & 3.182 & 4.418 & 3.215 & 4.742 \\
\hline Nucleer & 642 & 845 & 1.210 & 838 & 1.005 \\
\hline Hydro & 316 & 392 & 535 & 383 & 504 \\
\hline Bioenergy & 1.344 & 1.554 & 2.002 & 1.551 & 1.933 \\
\hline $\begin{array}{c}\text { Other } \\
\text { renewable }\end{array}$ & 142 & 308 & 918 & 289 & 658 \\
\hline TOTAL & 13.361 & 14.978 & 18.293 & 15.317 & 20.039 \\
\hline $\begin{array}{c}\text { The ratio of fuel } \\
\text { in the fossil (\%) }\end{array}$ & 82 & 79 & 74 & 80 & 80 \\
\hline $\begin{array}{c}\text { The ratio out of } \\
\text { OECD(\%) }\end{array}$ & 60 & 63 & 70 & 63 & 70 \\
\hline
\end{tabular}

\section{THE POTENTIAL OF RENEWABLE ENERGY RESOURCES IN OUR COUNTRY}

According to the Mediterranean Energy Perspectives (MEP) - Turkey Report prepared by Observatiore Mediterraneen de l'Energie (OME), fossil fuels that meet $90 \%$ of demand in 2012 as a resource in our country are dominant in energy demand. Request; Coal $(30 \%)$, oil $(28 \%)$ and natural gas $(32 \%)$. The remaining part is covered by renewable energy sources [6].

In our country, as in other countries, energy is produced from fossil fuels such as coal, oil, and natural gas. Fossil resources will cause problems in energy production in the coming years when we do not have enough reserves in our country and the damages it gives to the environment, and it will cause our external dependency.

IRTIIE Vol. 5, No. 1, 2015 ISSN 1314-8788 (print), ISSN 1314-8796 (online), doi: 10.15547/artte.2017.01.006 

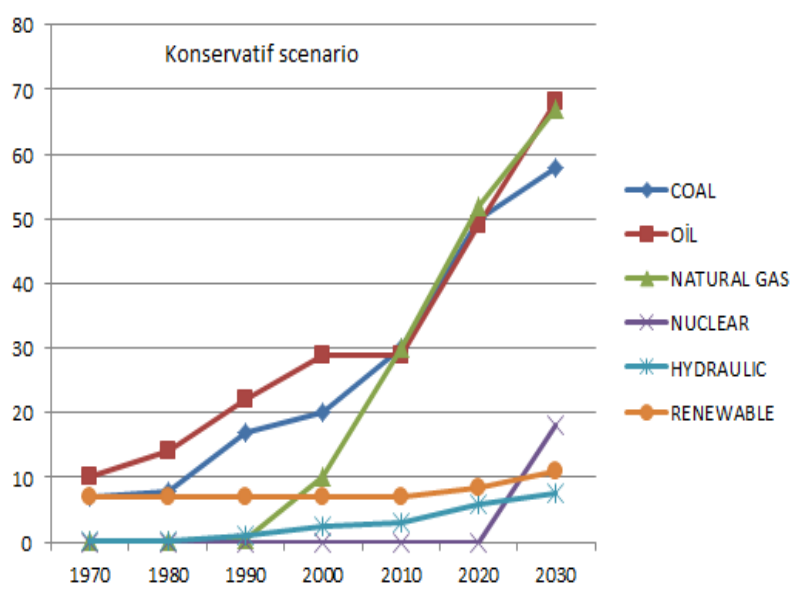

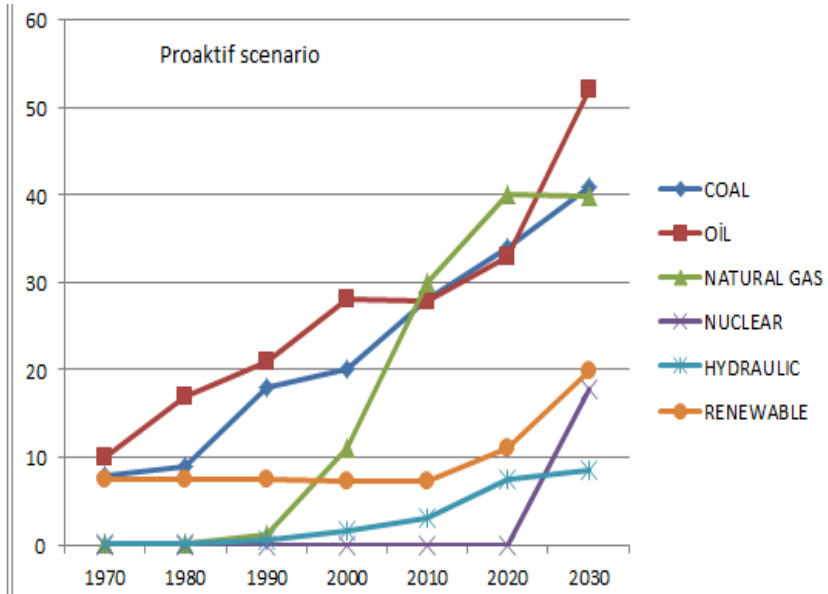

Figure 2.

Turkey's Primary Energy Resource Requirement (mtpe) between 1970-2030 [7]

If we look at the two graphs in Figure 2, the renewable energy source has increased since 2010 and it is expected to increase until 2030. As a renewable energy source, wind, sun and biogas are used in our country. These energy sources we use in terms of clean and renewable energy should be evaluated in our country. The Tenth Development Plan to be implemented between 2014-2018 is important in this respect. In the Tenth Development Plan; It is pointed out that renewable energy investments are increasing in the world. For this reason, it is pointed out that Turkey needs to increase energy production through renewable energy, that renewable energy will continue to be supported and encouraged, that maximum utilization of renewable energy is necessary due to dependence on some sources of energy imports and increase of domestic production level for necessary equipment in renewable energies. In this direction, Turkey aims to increase the share of renewable resources in energy production to $29 \%$ by 2018 [8].

\section{ANNUAL PRODUCTION OF RENEWABLE ENERGY RESOURCES IN TURKEY}

In our country, in terms of installed power, there are facilities that generate electricity from hydro, wind and geothermal energy sources, and in recent years the establishment of solar and biogas power plants has gained speed.

When Figure 3, 4, 5, and 6 are examined, the annual amount of wind energy production at the end of 2015 is 11.652 GWh in Country. The installed power of wind power plants operating until the end of September 2016 increased by $5.1 \%$ to $16 \%$ compared to the same period of 2015. By the end of June 2016 with the establishment of unlicensed electricity generation plants, while the number of solar power plants is seen as 673 , the total installed power of these plants is $505,9 \mathrm{MW}$. It is estimated that the amount of biogas that can be produced corresponding to Turkey's animal waste potency is $1.5-2$ million tons equivalent petroleum (MTEP) [10]. 


\section{IRTTIE}

Ipplied Researroches in Technics, Technologies and Eduration Journal of the Faculty of Technics and Technologies, Trakia University https://sites.google.com/a/trakia-uni.bg/artte/

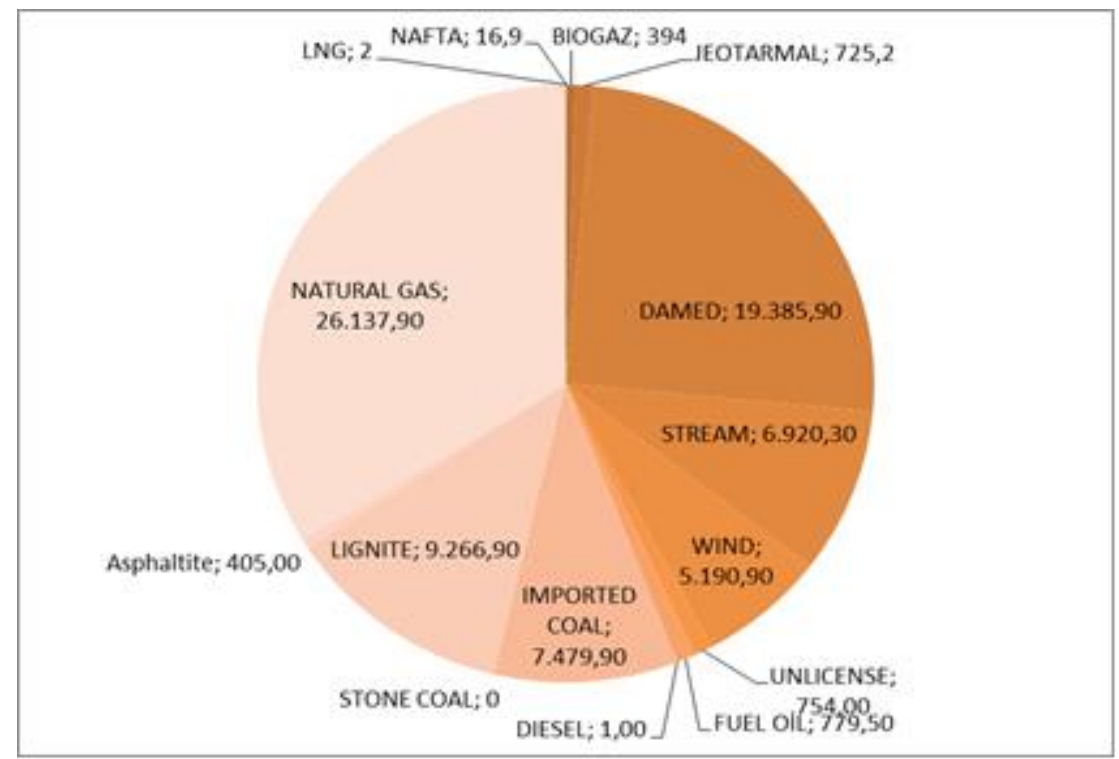

Installed power (09/2016): 78.102,8 MW

Figure 3. Electricity Power Installed Power in Turkey 2016 September [9]

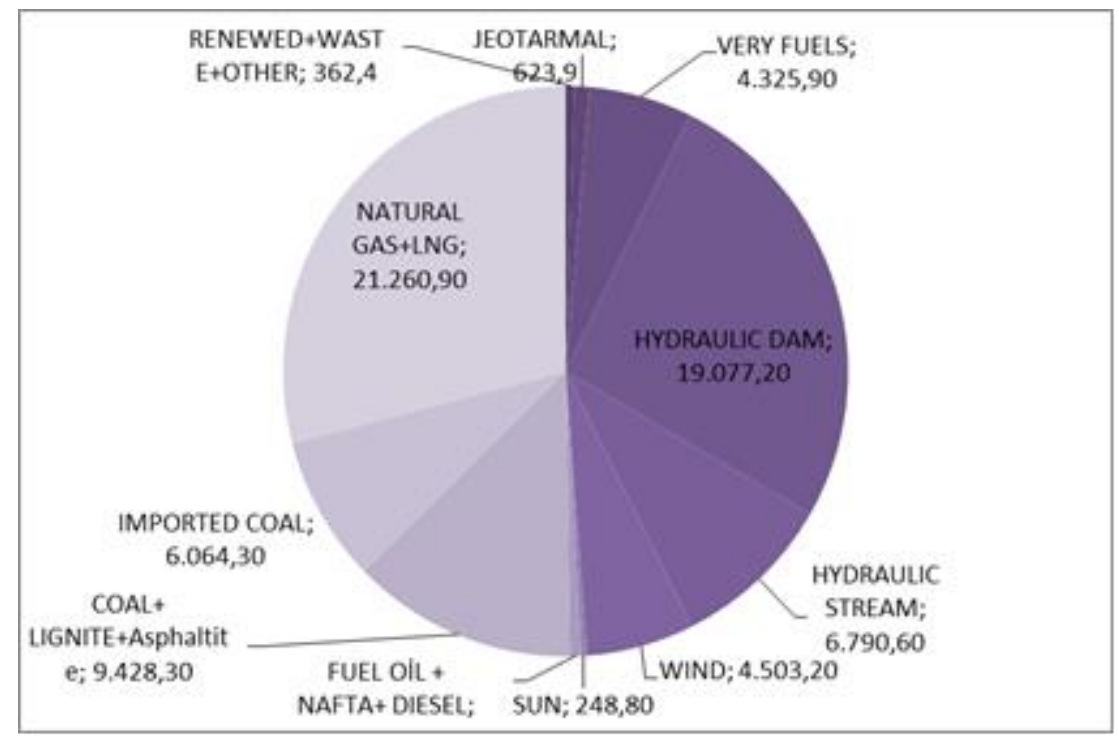

Installed power (2015): 73.146,7 MW

Figure 4. Electricity Power İnstalled Power in Turkey 2015 [9] 


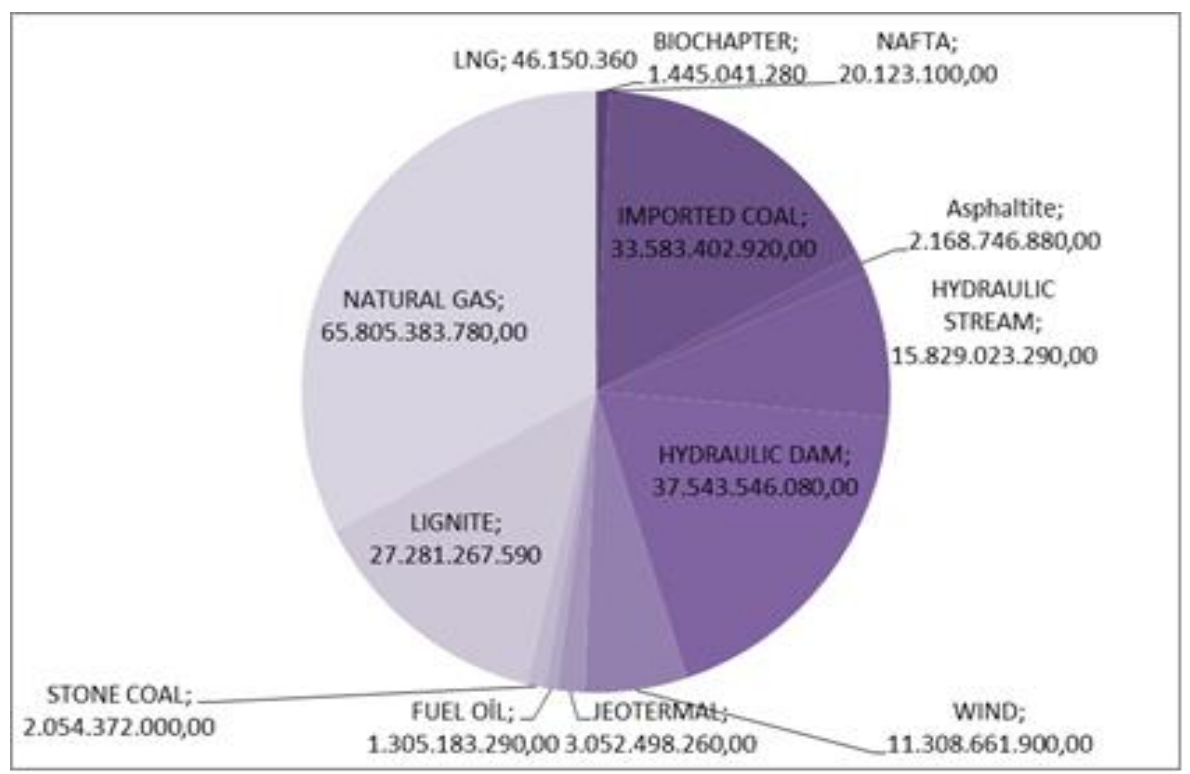

PRODUCTION (09/2016): 201.443.400.730 kWh [CONSUMPTION (09/2016): 205.164.582.990 kWh]

Figure 5. Electricity Generation in Turkey September 2016 [9]

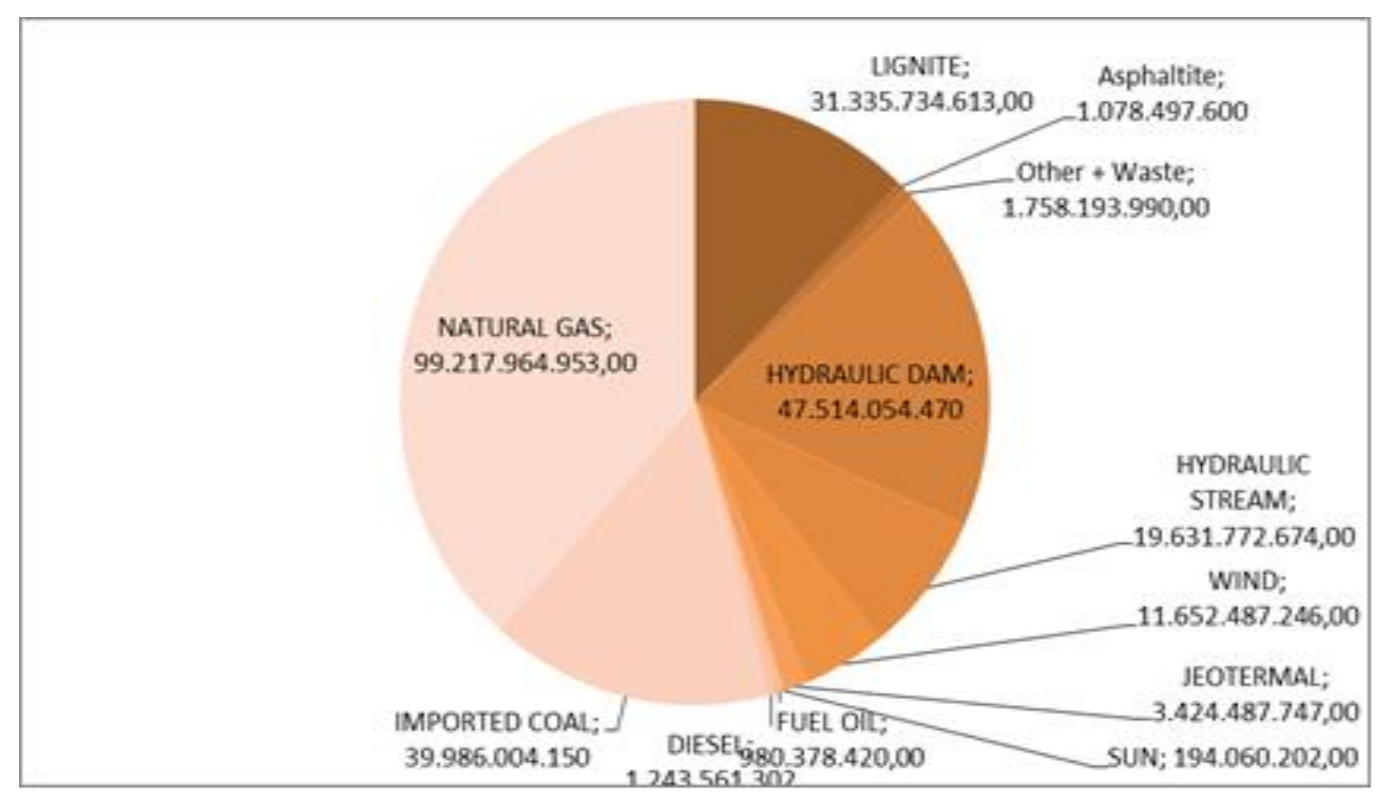

PRODUCTION (2015): $261.783 .303 .546 \mathrm{kWh}$ [CONSUMPTION (2015): 265.724.353.916 kWh]

Figure 6. Electricity Generation in Turkey 2015 [9] 


\section{ARTITIE}

Ipplied Researroches in Technics, Technologies and Eductition

Journal of the Faculty of Technics and Technologies, Trakia University https://sites.google.com/a/trakia-uni.bg/artte/

Table 2. Location of Turkish Electricity Market and TETAS between 2002 and 2015 [11]

\begin{tabular}{|c|c|c|c|c|c|c|c|c|c|c|c|c|}
\hline \multirow[b]{2}{*}{ YEARS } & \multicolumn{3}{|c|}{ PRODUCTION(GWh) } & \multicolumn{3}{|c|}{ IMPORT(GWh) } & \multicolumn{3}{|c|}{ EXPORT(GWh) } & \multicolumn{3}{|c|}{ CONSUMPTION(GWh) } \\
\hline & TÜRKIYE & $\begin{array}{c}\text { TETAŞ } \\
\text { (ENERGY } \\
\text { RECEIVED) } \\
\end{array}$ & $\begin{array}{c}\text { TETAS } \\
\text { SHARE } \\
(\%) \\
\end{array}$ & TÜRKIYE & TETAŞ & $\begin{array}{c}\text { TETAŞ } \\
\text { SHARE } \\
(\%) \\
\end{array}$ & TÜRKIYE & TETAŞ & $\begin{array}{l}\text { TETAS } \\
\text { SHARE } \\
(\%) \\
\end{array}$ & TÜRKIYE & $\begin{array}{c}\text { TETAŞ } \\
\text { (ENERGY } \\
\text { SOLAR) } \\
\end{array}$ & $\begin{array}{c}\text { TETAS } \\
\text { SHARE } \\
(\%)\end{array}$ \\
\hline 2002 & 129.400 & 106.230 & 82 & 3.588 & 3.588 & 100 & 435 & 435 & 100 & 132.553 & 101.990 & 77 \\
\hline 2003 & 140.580 & 113.170 & 81 & 1.158 & 1.158 & 100 & 588 & 402 & 68 & 141.151 & 109.370 & 77 \\
\hline 2004 & 150.698 & 120.690 & 80 & 464 & 464 & 100 & 1.144 & 379 & 33 & 150.018 & 116.820 & 78 \\
\hline 2005 & 161.956 & 128.890 & 80 & 636 & 636 & 100 & 1.798 & 412 & 23 & 160.794 & 125.420 & 78 \\
\hline 2006 & 176.300 & 122.220 & 69 & 573 & 573 & 100 & 2.236 & 564 & 25 & 174.637 & 118.610 & 68 \\
\hline 2007 & 191.558 & 89.110 & 47 & 864 & 864 & 100 & 2.422 & 1.215 & 50 & 190.000 & 87.350 & 46 \\
\hline 2008 & 198.418 & 86.950 & 44 & 789 & 789 & 100 & 1.122 & 152 & 14 & 198.085 & 85.340 & 43 \\
\hline 2009 & 194.813 & 84.457 & 43 & 812 & 812 & 100 & 1.546 & 331 & 21 & 194.079 & 83.027 & 43 \\
\hline 2010 & 211.208 & 87.032 & 41 & 1.144 & 932 & 81 & 1.918 & 627 & 33 & 210.434 & 85.263 & 41 \\
\hline 2011 & 229.395 & 82.284 & 36 & 4.556 & 415 & 9 & 3.645 & 19 & 0.5 & 230.306 & 80.754 & 35 \\
\hline 2012 & 239.497 & 83.557 & 35 & 5.827 & 317 & 5 & 2.954 & 13 & 0.9 & 242.369 & 82.214 & 34 \\
\hline 2013 & 240.154 & 131.079 & 55 & 7.429 & 277 & 4 & 1.227 & 0.2 & 0.01 & 246.357 & 129.597 & 53 \\
\hline 2014 & 251.963 & 123.149 & 49 & 7.953 & 103 & 1 & 2.696 & 0 & 0 & 257.220 & 121.604 & 47 \\
\hline 2015 & 259.690 & 113.039 & 44 & 7.411 & 0 & 0 & 2.947 & 0 & 0 & 264.137 & 111.815 & 42 \\
\hline
\end{tabular}

Electricity consumption of $132,553 \mathrm{GWh}$ in 2002 was $264,137 \mathrm{GWh}$ in 2015 . Electricity imports, which were $3.588 \mathrm{GWh}$ in 2002, increased by $100 \%$ to $7.411 \mathrm{GWh}$ in parallel with the increase in electricity consumption in 2015. However, when looking at the electricity export figures, the exports which were 435 GWh in 2002, increased $477 \%$ in 2015 and reached $2.947 \mathrm{GWh}$. It can be said that electricity exports will reach much larger numbers if renewable energy is used more.

\section{CONCLUSION}

Having renewable energy in our country, increasing the share of this energy in energy production will reduce energy dependency on the outside. When solar power plants are evaluated, we are well in terms of the number of annual sunny days, annual sunshine periods, and the amount of annual solar radiation, and it turns out that we have high potentials as a result of research. It is estimated that wind, geothermal and biogas plants will increase in our country in the coming years as well as solar power plants.

Given the distribution of electricity generation, consumption, imports, exports and renewable energy, it is first thought that electricity production should be increased at very high levels. In order to increase electricity production, it is thought that we can increase our production by using renewable energy resources in consideration of environment and recycling.

The incentives for renewable energy sources are increasing. By using this situation, we will have a clean energy source and a clean air field, as if there is no air pollution, as we reduce the dependency on the outside with the energy we produce when the appropriate power plants are installed. Utilizing incentives, our public institutions and our industries will be able to produce troubles in the coming years when we can not produce renewable energy. 


\section{RESOURCES}

[1] Çınar, S., Yılmazer, M., Renewable Energy Sources Determinants and Economic Growth Relation:An Example of Emerging Countries, Journal of Dokuz Eylül University Faculty of Economics and Administrative SciencesSkin: 30, Number:1, Year:2015, pp. 55-78. (in Turkish).

[2] Turkey's Energy Profile and Strategy. [online]. Available: http://www.mfa.gov.tr/turkiye_nin-enerji-stratejisi.tr.mfa. [08.04.2017].

[3] International Renewable Energy Agency (IRENA) 'Renewable Capacity Statistics 2016 report (in Turkish). [2016].

[4] IEA - World Energy Outlook 2015. [2015].

[5] International Energy Agency, World Energy Outlook (WEO) 2014 (in Turkish),

[6] 2014 Sector Report. [online]. Available: http://www.enerji.gov.tr/File/?path=ROOT\%2F1\%2FDocuments\%2FSekt\%C3\%B6r\%20 Raporu\%2F2014\%20Y\%C4\%B11\%C4\%B1\%20Sekt\%C3\%B6r\%20Raporu.pdf. [08.04.2017].

[7] 2014 Sector Report. OME - MEP Turkey.

[8] Özer, Y.E. 'Comparative analysıs of Turkey on clean and renewable' Hitit University Social Sciences Institute Magazine, [S.I.], v. 9, n. 1, jun. 2016. ISSN 1308-5107. (in Turkish).

[9] Chamber of electrical engineers. [online]. Available: http://www.emo.org.tr/ekler/a9d554384f0a14f_ek.pdf. [19.10.2016].

[10] MTEP. [online]. Available: http://www.enerji.gov.tr/. [08.04.2017].

[11] TETAŞ 2015 Annual Activity Report, Turkey Electricity Trading and Contracting Co. General Directorate (TETAS), Ministry of Energy and Natural Resources, Ankara, 2016. (in Turkish). 